\title{
ALGORITHMIC DESIGN TOOLS IN DESIGN PROCESS
}

\author{
Daryanto; Firza Utama \\ Jurusan Arsitektur, Fakultas Sains dan Teknologi, Binus University \\ Jl. KH. Syahdan No. 9, Palmerah, Jakarta Barat 11480. \\ daryanto@binus.edu; firza.utama@binus.ac.id
}

\begin{abstract}
This article explores algorithmic design methods in a design process that uses natural phenomena as the basis of its architectural morphology. It implements digital morphogenesis in reaction to ecology and the influential forces of the building environment. This paper is divided into two equally important sections: the process description and the project implementation. The description of the process demonstrates the methods used and the idea involved in incorporating nature's influential elements as part of the creative task. Meanwhile, the project implementation showed practical case of the outcome of that process. Tools for visualizing and simulating nature's environment are showed using algorithmic design method. The tools create transformations in NURBS-based surfaces through the translation of their respective control point matrices. The tools generate several different alternatives to be tested and analyzed.
\end{abstract}

Keywords: morphogenesis, ecology, algorithmic design.

\begin{abstract}
ABSTRAK
Penelitian ini menelusuri metode desain dalam proses desain dengan menggunakan algoritma yang menggunakan fenomena alam sebagai dasar dari morfologi arsitekturnya. Makalah ini dibagi menjadi dua bagian penting, yaitu penjabaran proses dan penerapannya dalam proyek khusus. Penjabaran proses memperlihatkan metode-metode dan pemikiran yang dipakai ketika menggabungkan pengaruh alam dalam pencarian bentuk. Sedangkan bagian penerapan memperlihatkan contoh praktis dan output dari proses yang perlihatkan sebelumnya. Visualisasi dan pensimulasian alam ditampilkan dalam metode perancangan menggunakan algoritma dengan membuat transformasi bentuk permukaan NURBS melalui titik-titik pengontrol. Metode ini dapat menghasilkan beberapa alternatif yang masing-masing akan diuji dan dianalisis.
\end{abstract}

Kata kunci: morfogenesis, ekologi, desain algoritmik. 


\section{INTRODUCTION}

The field of architecture is going through a shift where its basic principles are being challenged by the changes that happen around. The abundance of new techniques and technologies in architectural design, as well as in fabrication and construction, forces us to look over our design methods and processes. The global changes that drive us toward an ever-growing need for technology in buildings provide us the opportunity to search for new holistic solutions. However, the new solutions cannot be made with obsolete tools. Michael Weinstock states that the direct emulation of the past is fruitless, yet we must learn from the lessons it provides (Hensel \& Menges, 2008).

New architectural paradigms are formed with the help of the transition to digital design - new tools that allow us to find new sources of inspiration and solutions. However, these tools only imitate the old design processes and do not create any new possibilities or inspiration for design. Kostas Terzidis (2006) states that they offer the benefits of computerization but not the overwhelming opportunities of computing.

The use of scripting and parametric software offers potentials to designers to search for optimal results through the whole design process. It offers the incorporation of interdisciplinary knowledge to the early stages of the process, that it can influence the rationality of the outcome and even try to solve the problems in sequential order. The changes in the design process gradually happen. With the digital integration of architecture, engineering and biological processes, it will affect architecture in the future.

\section{Algorithmic Design Tools}

Algorithm is not only about software and computers, but also describes a process of logical thinking as the early computer does. They are commonly associated with computer science, as the term is mostly used there, but essentially the use of instructions, commands and rules in architectural practice is using algorithm. Many of our design choices are controlled by laws and regulations, and certain decisions rule out or enable new options. As with algorithms, we are also controlled by if-thenelse conditional choices. We make decisions based on validated data and those decisions guide us through the design process (Terzidiz, 2006).

Terzidis points out, that design is about conceptualization, imagination and interpretation. It is the activity of formulating ideas, that is about accomplishing a pre-set objective. Design should leave room for serendipity - a chance to find something completely unexpected, yet desired. It cannot be achieved by conforming to current rules and practices. It applies the use of algorithms as well; if we control the final result with over-specific rules, we will leave no room for new emerging forms. There is no point in designing something, if you already know the final outcome.

Algorithms is only a single tool used in design process, not the whole design process. Meanwhile, design is strongly influenced by the tools utilized, so conversely, tools have a profound effect on the design (Terzidiz, 2006). Some claim that the prolific use of computers in design produces recognizable results in form and structure. This seems to be a critique toward computer models, as though a computer had played a determining role in forming the design. Terzidis explains that the mouse-based manipulation of control points on NURBS-based (Non- uniform rational B-Spline) or mesh surfaces is not an act of computing, as much as its transformations, completely based on the visual decisions of the designer. The use of the computer or computing in architectural design does not dictate any pre-defined shapes or style. However, with the help of algorithmic design methods, as designers we are allowed to extend our creativity. 
Using an open design process and incorporating the use of different design branches simultaneously, rather than consecutively, we can search logical and effective options. To make it work, we must roam beyond our traditional comfort zone and Terzidis suggests that this might be the first architectural design which is not aligned with formalism or rationalism but with intelligent form and traceable creativity. The use of these new methods does not limit the intuition of the designer or the form of the design. As change can only be additive, not subtractive, they do not reject or deny existing approaches to design (Achim, 2006).

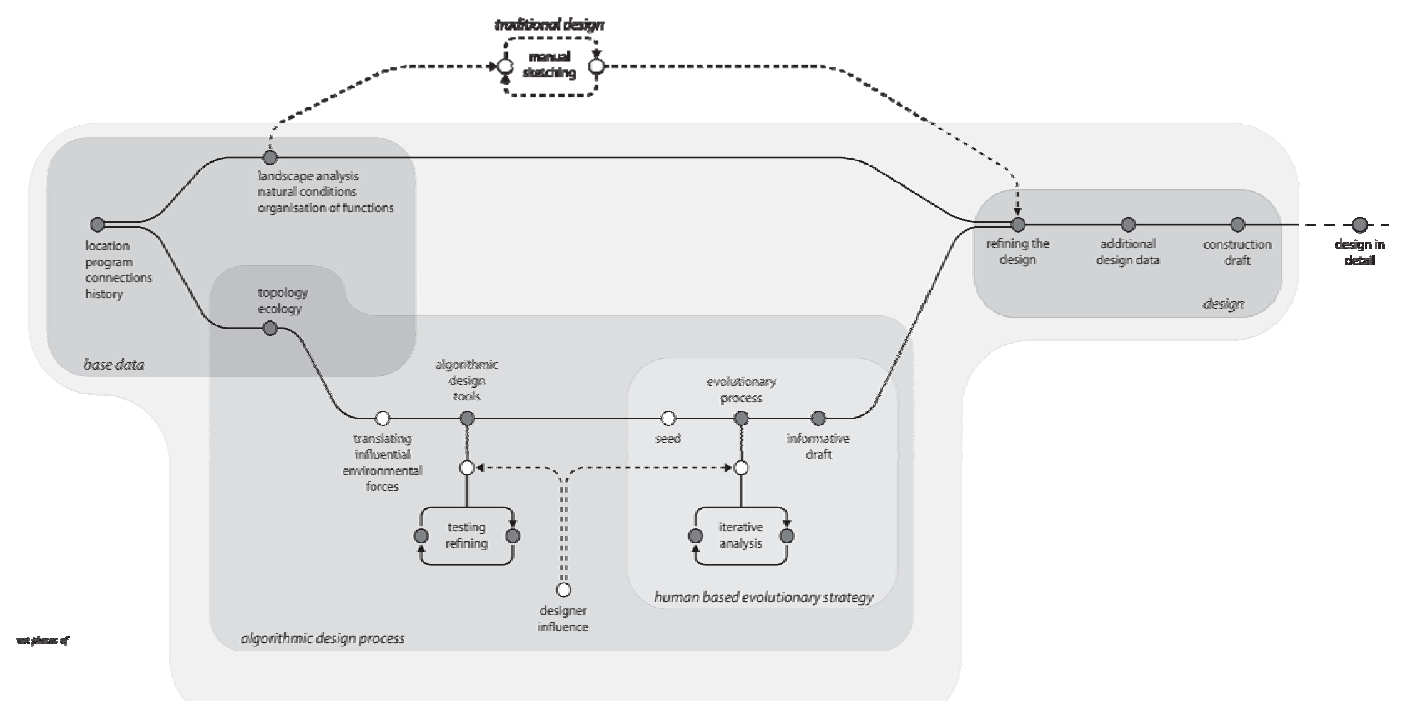

Figure 1. Diagram of different phases in design process.

\section{Digital Morphogenesis}

Natural organisms are form through evolution that requires numerous generations of mutation and genetic selection. An organism's DNA holds a coded sequence that controls their growth. As a general rule, nature tries to do things as simply as possible. Their mechanics may, at first, seem incomprehensibly complex but underneath lays a set of very simple algorithms (Hensel et.al, 2008). Many of the emergent algorithms to be used in our design are based on these natural processes.

Terzidis (2006) points out that the processes may not be regarded as human inventions but human discoveries. Genetic Algorithms, Cellular Automata and Voronoi Diagrams are just a few examples of nature's ingenuity that we often exploit in contemporary architectural design (Coates, 2010). Estévez and Puigarnau (2003) say that the new methods in architecture allow us to not simply create in the nature, but to create with the nature.

Natural morphogenesis is a process of evolutionary development and growth. It produces polymorphic systems that obtain their complex organization and shape through interaction between their material capacities and the external environmental influences and forces, as described by Achim Menges (2006). This process gives the organism its distinctive shape and internal cellular structure. We can use simulation of the mathematical representation of the interaction of real-world objects for the benefit of architectural design. Using evolutionary methods and the active modulation of simulated environmental conditions, the morphological differentiation of form and structure can emerge.

Several attempts to find finite and, in some ways, completed geometrical forms which will be ruined when they are added to or removed from, are defied by the nature's total disrespect towards them. Reima Pietilä (1958) calls them terminable and interminable objects, where terminable objects 
find a state of completion and interminable objects that allow infinite enrichment both qualitatively and quantitatively. Though, the "completion" of an object is indicative of the inner tensions of the composer which are, as such, more than a psychological expression.

During morphogenesis, natural or digital, an organism is in a constant state of change. Whether through growth or environmental factors, every moment is different in structure and composition. Because of this, every single moment in its composition is as meaningful and as beautiful as the subsequence and we cannot point at a moment of completion. Nature is never completed nor is it ever exactly the same. Derived from the way in which nature works, the way a simulation of how nature should work is based on our choice of a point where we are satisfied with the results. Using these methods in architecture, we cannot expect a "finished" product, optimized to perfection, but we will receive a form that is just a snapshot in its evolutionary history.

\section{Ecology}

Michael Hensel (2006) describes ecology as the interdisciplinary, scientific study of the relation between an organism and their hosting environment. It can be studied at various levels ranging from the individual organism to populations, communities of species, ecosystems or even the whole biosphere. The specific host environment is in constant and dynamic feedback relation with the organism, which evolves functionality.

As a term, ecology can be expanded to describe a way of thinking that leans towards sustainable living. In this case, ecology implies actions that influences our environment as little as possible or does not leave long-term effects. Sustainable living tries to minimize the effects of man on his environment. The use of the term in this paper is not in its expanded meaning, but in its original root where it describes the study of the relationship between organism and its environment (Hensel et.al, 2008). As such, the term does not imply or hold any indication of the nature of this relationship or the possible impact the organism and the environment have on each other.

Environment is a collective term for a condition in which an organism lives. It is the complex and dynamic exchange between these two that enables evolving functionality, as stated by Hensel (2008). As external environmental factors influence the development of form and function, it makes the environment subject interesting in architectural design field. Hensel (2008) points out, that the response to external stimuli could be in the core of the generative process of architecture, instead of the consecutive step-by-step, objective-by-objective optimization at the end of the design process.

Ecology enables mutation in genetic processes, as it acts as a motivation for the form or structure to evolve to be better suited in surviving in its environment. The simulation of mutation and its effects are completely in the hands of the designer who makes the decision for the best solution of a population that will be calculated. One criterion for that can be the structural optimization of a form, but it does not count all the effects of the environment, but only a narrow sector of the physical forces affecting the form, even a very crucial force in the realization of a construction. Different factors can be used in the mutation of the form as well as in the criteria on which the fittest solution is evaluated.

\section{METHOD}

\section{Parametric Experiment}

The link between environmental data, which becomes available through simulation and the impact it has on the design process, is further explored. The natural environmental forces that affect 
the experiment are too complex and enumerable to simulate to their full extend. Because of that, the simulations were limited to only a few decisive factors that would hold the most influence in the mutation. CFD (Computational Fluid Dynamic) simulation was used to provide information on the performance of the configuration and its components.

\section{Deciding Influential Forces}

The algorithmic and parametric tools work consecutively on the object and they are applied with different settings so that their effects vary over different prodigies. The tools provide an external agent that produces a reaction within the object, which then recognizes the reaction and translates that reaction into a transformation of its control point. The order in which the tools are applied, have some effect on the overall morphology of the solution.

The environmental toolset is applied to the generation with varying parameters for a finite amount of times. It produces a small population for visual evaluation, from which the fittest solution will be selected to become the next generation. Through evolutionary methods and consecutive generations of different solutions, the shape and form of the final solution slowly starts to emerge.

The purpose of the toolset is to simulate into a certain accuracy of the behavioral characteristics of natural and visual forces, and what most important is to convert the information into the transformation of a simulated surface. Through consecutive runs, or iterations of the tools, the effects on the surface become clearer after all new iteration is done. The tools are designed with different parameters that control the amount of their effects and allow a certain degree of variation in their application, enabling different compositions of environmental forces. Using the tools with varying settings causes different results in parallel runs.

The affected object is represented by a NURBS (Non-Uniform Rational B-Spline) - based surface that is controlled by a matrix of control points and their weights. Regarding to the Bézier curves, it allows local modification of the surface by changing the control point coordinate, without affecting the rest of the surface31. The level of detail, and thus the level of effect that the tools have on the surface, is controlled through the density of the control points. As the move of a control point affects the surface only locally, their degree and density dictates the shape and the amount of the transformation.

The modification of the surfaces is controlled through the modification of their respective control points. The resolution of the control points can be used to control the complexity of the solution. The surface's resolution also determines the detailing level of that the tools have on it; more control points on a surface means a more defined result. The amount and direction of the transformation is directly controlled by the individual tools which all function differently from each other in order to facilitate force-specific results. The tools are applied through scripting and the use of parametric application. The simulation environment was created using Rhinoceros 4.0 threedimensional modeling program based on NURBS and a parametric plug-in, called Grasshopper.

All different simulated environmental and visual forces function through the displacement of the surface's control points. The vector for each transformation is calculated through the internal algorithm of the tool in question and each force's effect on the surface is unique. The amount of single transformation is relatively small, but the cumulative effects of the forces yield distinctive results (Figure 5).

\section{Algorithm: Pseudocode}

The algorithm of the simulation can be described as Pseudocode as follows: For each 
individual in the population $>$ create a surface using genes as parameters in the surface equation $>$ attach the control points of the surface to a set of springs $>$ run the physics simulation between the springs until the surface reaches equilibrium (Figure 2) $>$ attach hexagonal pattern to the surface $>$ calculate the normals of the surface $>$ attach the normals to the fluid's vector field $>$ create particle system and add its density to the fluid' density field (Figure 3) > run the computational fluid dynamics for the particle system $>$ calculate the rate of particle entering the core volume over generated particles and evaluate the invidual (Figure 4).

\section{RESULTS \& DISCUSSION}

In order to discuss the practical example of morpho-ecological design, the work of R\&Sie(n) are presented and discussed. The pictures, plans, diagrams of R\&Sie(n)'s projects show the use of modeling and scripts, values in understanding the behavior of nature, and its interaction with urban structure, and the complexity of the design process. By using morphogenetic and parametric tools, they try to demonstrate that nature cannot be domesticated and predictable. R\&Sie(n) uses these tools to question the evolution of nature and its interaction with urban elements of housing.

An interesting evolution in R\&Sie(n)'s research and a focus on ecology can be seen from the system of evolutionary development and diversification (phylogenesis). R\&Sie(n) questions the way nature and molecular nature of cities interaction. Nature is unpredictable so that it cannot be easily domesticated and the notion of "contingent" is appropriate. They have re-appropriated this notion in their research on ecological architecture and urbanism. Their latest project I'm Lost in Paris (20082009, Figure 6) examines how the intrusion of nature (fern) causes stress, not only to the plants but also to the inhabitants of a quiet Haussmannian-style housing since R\&Sie(n) nature is reactive and not proactive. I'm Lost in Paris is an ecological house with 1200 ferns growing around the building. The ferns get fed from hydroponic tubes that carry water from the roof to the plants. The choice of this plant is strategic. As we know, there is a strong relationship between a mass of plant form and its lifespan. Big plants live longer than small ones, as noted Michael Weinstock (2006). Michael Weinstock has undertaken research since a decade on the interaction of biological elements evolution. He found similarities between the biological structure and parametric, as well as morphogenetic architecture and urbanism. As he wrote, "Plants are hierarchical structures, made of material with subtle properties that are capable of being changed by the plant in response to local or global stresses.

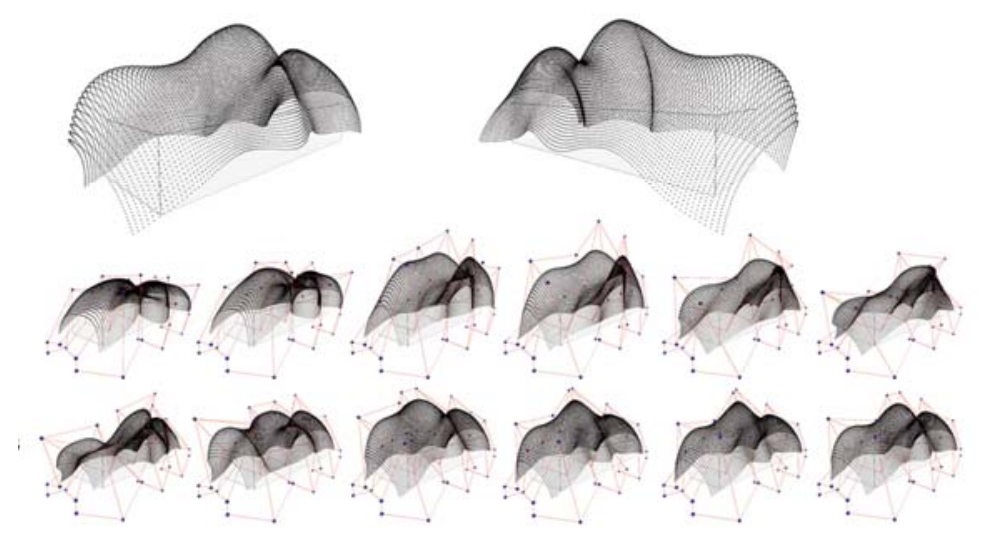

Figure 2. Created surface using genes as parameters (above). Attached are control points to the surface running physics simulation. 

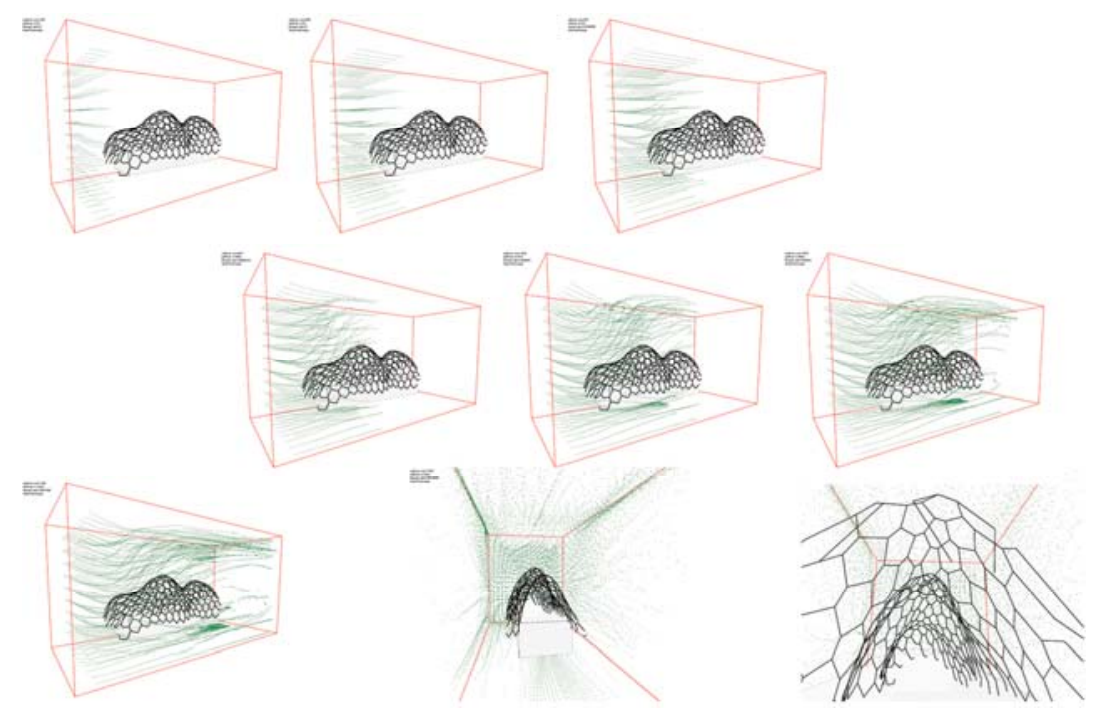

Figure 3. Created particle system and its density to the fluid's density field.

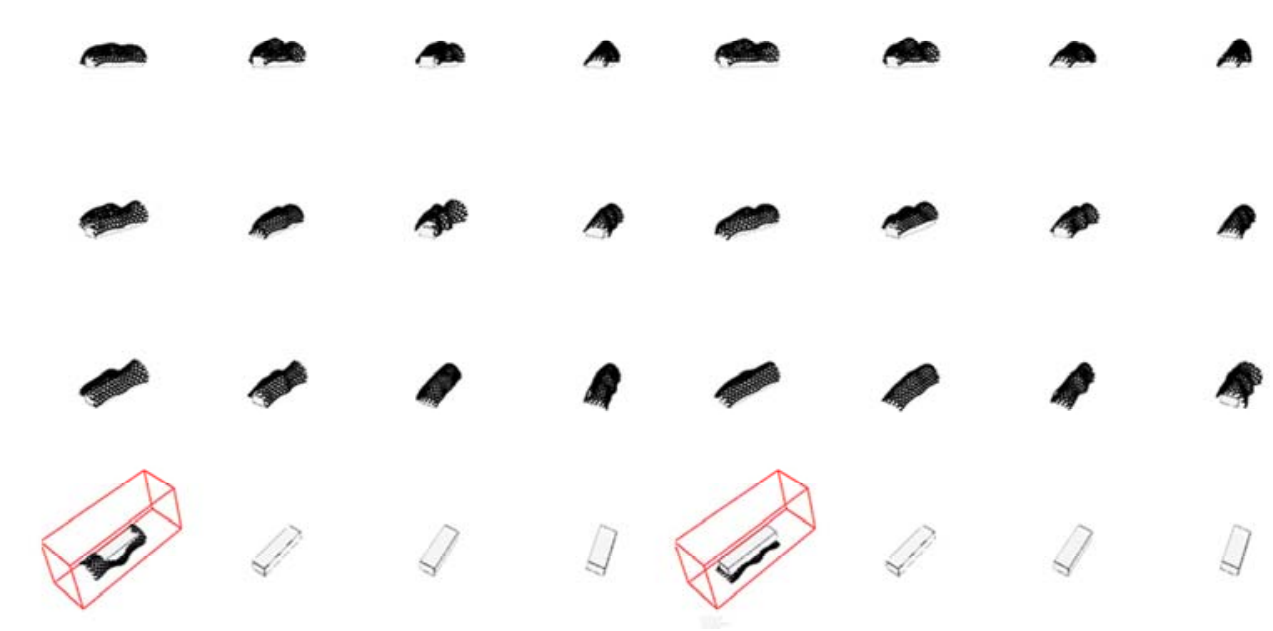

Figure 4. Individual evaluation of particle rates entering the volume over the generated solution.
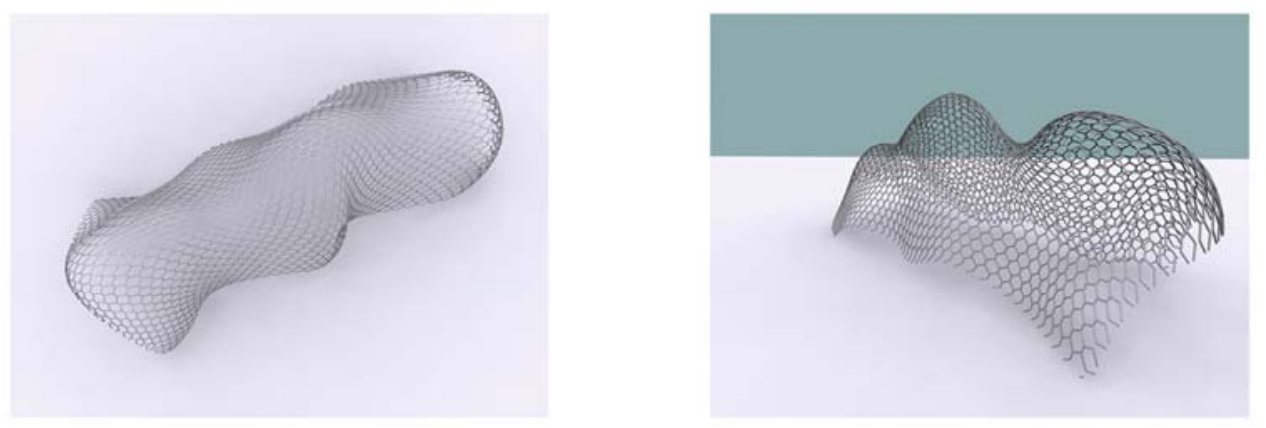

Figure 5. Simulation result. 

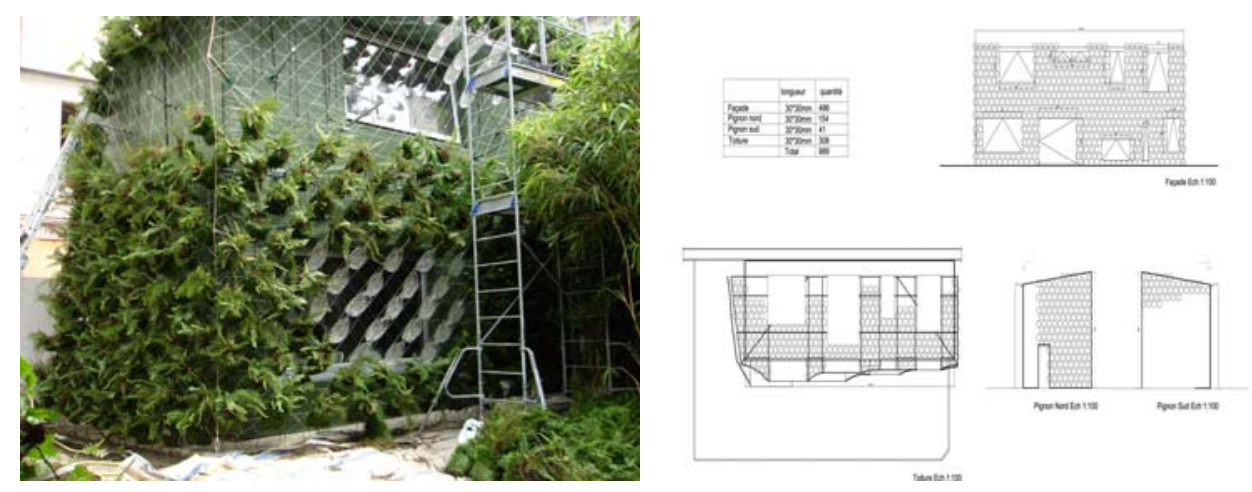

Figure 6. R\&Sie(n) I'm Lost in Paris project.

A similar project namely Spider Net in the Wood constructed by R\&Sie(n) in 2007 (Figure 7), confirms Michael Weinstock's assertion. The scenario is clear and simple: over density of existing forest plantation (trees will be at the right level in 5 years). R\&Sie(n) has posted a series pictures of the plant evolution a year after the construction entitled Growing plants. As we can see, plants gradually seem to absorb the house. The structure is made by netting and wrapping the forecasted size of adult trees with a polypropylene mesh in order to develop a labyrinth in the branches. The house consists of $400 \mathrm{~m}^{2}$ indoor stealth building plugged and connected to the labyrinth by a sliding glass door. The house functions as the "principle of plants": it is unpredictable, self-organizational. It aims to demonstrate the building as plants that are capable of being changed in response to local or global stresses. This house is a prototype of François Roche and Stéphanie Lavaux's interest for the behavior of building stressed by nature. The plan of the house shows the relationship of the building and its surrounding environment. Nature will gradually control the building and it will be absorbed by its surrounding environment. From the concept of adaptive in R\&Sie(n)'s architectural projects, we may conclude that the building functions as the plants. It will be obliged to manage the plants activities as they will resist the high technology-made structure. Plants as well as the building function in the same way. Precisely, building needs to capture light and ventilation as it will exchange gases like metabolic structures.

We may take the Mosquito Bottleneck project (Figure 8), a house project built in 2003 as an example of an art collection in Trinidad. The design is adopted from mosquito movement. The movement produces a simple form that will be assembled to form a complex structure which will be self-assembled into a more complex structure, and so forth. The descriptions and digital models permit a better understanding of the structural performance not only of the biological structure (the mosquito, surrounding environment, ferns) but also of the building.
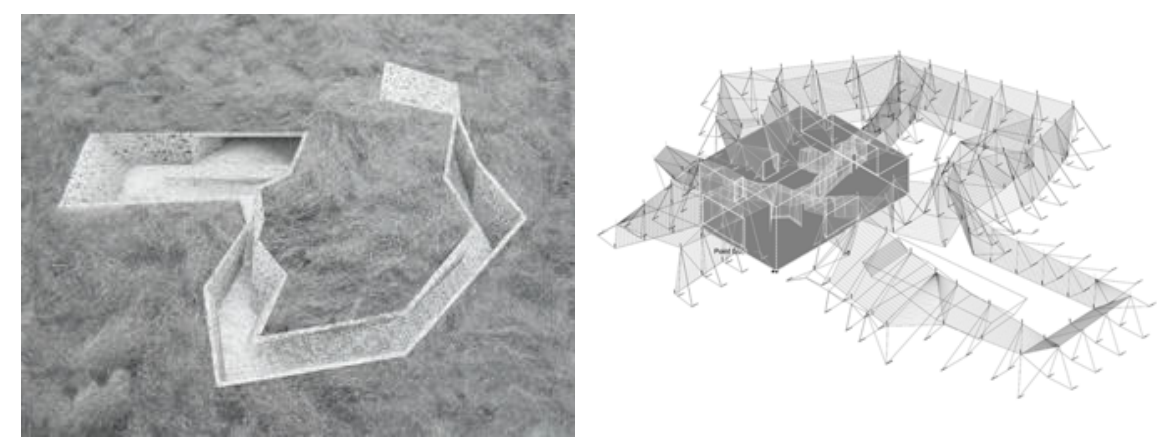

Figure 7. R\&Sie(n) Spider Net in the Wood project. 
In the case of Mosquito Bottleneck, the mosquito movement turned into a "Klein-bottle twist" between the two contradictory data: that of humans and that of insects. It is interesting to note that the architects used a fragile structure and materials for the building simulating the fragility of the mosquito lifespan and human's fragility against viruses. The building skin consists of plastic wire and plastic shrink-warp to weave together with the house from the floor to the roof. It is made to build a skin that will actually attract mosquitoes and move them through the building, while of course, keeping them separate from the occupants. The result is the dwelling structure which behaves like mosquitoes as it vibrates like the way mosquitoes buzz.

Digital models facilitate the construction of the following projects: Mosquito Bottleneck, Spider in the Wood, and I'm Lost in Paris. The models enable analysis and simulations. The mosquitoes natural behavior is then shifted into a structural behavior that will be modeled, then, scripted with the use of a lot of softwares varied from 3D to mathematical ones. The analysis of natural environment leads to the house construction that will be progressively controlled by nature. Conversely, the intrusion of nature (the ferns) in an urban environment has previously been simulated with advanced tools in order to draw various scenarios of relationship and conflict between nature, urban environment and humans, etc.
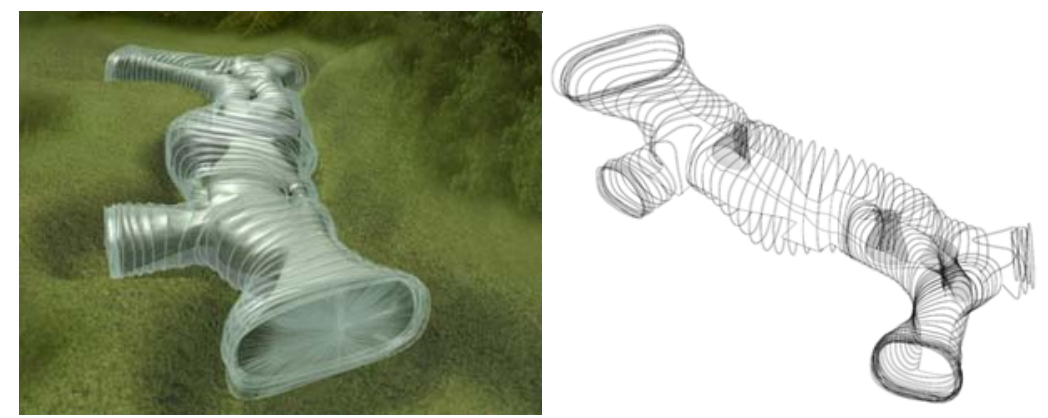

Figure 8. R\&Sie(n) Mosquito Bottleneck project.

\section{CONCLUSION}

In conclusion, the morpho-ecological strategies are permitted to test and simulate at various scale behaviors, and scenarios that will then be reinterpreted into meaning, architecture, and engineering. They reveal an agenda for new strategies in terms of not only design but also construction - that is a new system for advanced architectural engineering.

\section{REFERENCES}

Achim, Menges. (2006). Instrumental Geometry. Architectural Design, 06 (02). New Jersey: John Wiley \& Sons.

Achim, Menges. (2006). Polymorphism. Architectural Design, 76(02). John Wiley \& Sons Ltd.

Coates, Paul. (2010). Programming Architecture. New York: Routledge.

Estévez, A. T., Puigarnau, A. (2003). Genetic Architectures. Barcelona: Lumen. 
Hensel, M. \& Menges, A. (2008). Morpho-Ecologies - Towards an Inclusive Discourse on Heterogeneous Architecture (2nd ed.). London: Architectural Association.

Hensel, Michael. (2006). Computing Self-Organisation: Environmentally sensitive Growth Modelling. Architectural Design, 76.

Pietilä, Reima. (1958). Morphology of Expressive Space.

Terzidis, Kostas.(2006). Algorithmic Architecture. Amsterdam: Elsevier.

Weinstock, Michael (2006). Techniques and Morphogenetic of the Architectural Design. Architectural Design. New Jersey: John Wiley \& Sons. 